\title{
Preparation of Monoclinic Pyrrhotite by Thermal Decomposition of Jarosite Residues and Its Heavy Metal Removal Performance
}

\author{
Cuimin Xu (D), Qiaoqin Xie, Fan Xu, Yuefei Zhou *®D, Hanlin Wang, Tianhu Chen and Shuchuan Peng
}

Citation: Xu, C.; Xie, Q.; Xu, F.; Zhou,

Y.; Wang, H.; Chen, T.; Peng, S.

Preparation of Monoclinic Pyrrhotite

by Thermal Decomposition of Jarosite Residues and Its Heavy Metal

Removal Performance. Minerals 2021,

11, 267. https://doi.org/10.3390/

$\min 11030267$

Academic Editor: Jean-François Blais

Received: 5 February 2021

Accepted: 26 February 2021

Published: 5 March 2021

Publisher's Note: MDPI stays neutral with regard to jurisdictional claims in published maps and institutional affiliations.

Copyright: (c) 2021 by the authors. Licensee MDPI, Basel, Switzerland. This article is an open access article distributed under the terms and conditions of the Creative Commons Attribution (CC BY) license (https:/ / creativecommons.org/licenses/by/ $4.0 /)$.
Key Laboratory of Nanominerals and Pollution Control of Anhui Higher Education Institutes, School of Resources and Environmental Engineering, Hefei University of Technology, Hefei 230009, China; 2018170628@mail.hfut.edu.cn (C.X.); qqxie424@hfut.edu.cn (Q.X.); xufan9@mail.hfut.edu.cn (F.X.); hanlinwang@mail.hfut.edu.cn (H.W.); chentianhu168@vip.sina.com (T.C.); Pengshuchuan@hfut.edu.cn (S.P.)

* Correspondence: alphazhou@hfut.edu.cn

\begin{abstract}
Jarosite residues produced by zinc hydrometallurgical processing are hazardous solid wastes. In this study, monoclinic pyrrhotite (M-Po) was prepared by the pyrolysis of jarosite residues in $\mathrm{H}_{2} \mathrm{~S}$ atmosphere. The influence of gas speed, reaction temperature, and time was considered. The mineral phase, microstructure, and elemental valence of the solids before and after pyrolysis were analyzed using X-ray diffraction, scanning electron microscopy, and X-ray photoelectron spectroscopy, respectively. The performances of the prepared M-Po on the removal of $\mathrm{Zn}$ and $\mathrm{Pb}$ from aqueous solution were evaluated. The results show M-Po to be the sole product at the reaction temperatures of 550 to $575{ }^{\circ} \mathrm{C}$. Most of the M-Po particles are at the nanometer scale and display xenomorphic morphology. The phase evolution process during pyrolysis is suggested as jarosite $\rightarrow$ hematite/magnetite $\rightarrow$ pyrite $\rightarrow$ pyrite $+\mathrm{M}-\mathrm{Po} \rightarrow \mathrm{M}-\mathrm{Po}+$ hexagonal pyrrhotite $(\mathrm{H}-\mathrm{Po}) \rightarrow \mathrm{H}-\mathrm{Po}$. The formation rate, crystallinity, and surface microtexture of $\mathrm{M}$-Po are controlled by reaction temperature and time. Incomplete sulfidation may produce coarse particles with core-shell (where the core is oxide and the shell is sulfide) and triple-layer (where the core is sulfate, the interlayer is oxide, and the shell is sulfide) structures. M-Po produced at $575{ }^{\circ} \mathrm{C}$ exhibits an excellent heavy metal removal ability, which has adsorption capacities of $25 \mathrm{mg} / \mathrm{g}$ for $\mathrm{Zn}$ and $100 \mathrm{mg} / \mathrm{g}$ for $\mathrm{Pb}$ at $25^{\circ} \mathrm{C}$ and $\mathrm{pH}$ ranges from 5 to 6 . This study indicates that high-temperature sulfidation is a novel and efficient method for the treatment and utilization of jarosite residues.
\end{abstract}

Keywords: jarosite residues; hazardous solid waste; sulfidation; pyrrhotite; adsorption

\section{Introduction}

Jarosite residues containing mainly iron sulfates and jarosite $\left((\mathrm{Na}, \mathrm{K}) \mathrm{Fe}_{3}\left(\mathrm{SO}_{4}\right)_{2}(\mathrm{OH})_{6}\right)$ are byproducts of the traditional hydrometallurgy industry [1-3]. In addition to $\mathrm{Fe}$ and $\mathrm{S}$, jarosite residues also contain considerable trace elements, such as $\mathrm{As}, \mathrm{Cd}, \mathrm{Cu}, \mathrm{Pb}, \mathrm{Zn}, \mathrm{In}$, $\mathrm{Co}, \mathrm{Ge}$, and $\mathrm{Ag}$, which are originally involved in the raw zinc ores [4,5]. Under natural conditions, these heavy metals are easily leached from jarosite residues and dispersed into rivers, soils, and other environments, threatening the health of wildlife. Therefore, in many countries, jarosite residues are required to be stored in specific installations for safety $[6,7]$. Though effective, this temporary method has its shortcomings. It not only induces a series of potential environmental problems but also occupies massive land resources. Thus, some comprehensive utilization proposals that aim to reuse jarosite and recover key metals are provided.

Typical efforts to treat jarosite residue include developing clean hydrometallurgical technologies $[8,9]$, recovering valuable metals $[10,11]$, and preparing special materials as additives $[12,13]$. In the building industry, jarosite residues are added into building bricks $[14,15]$, subgrade filler $[16,17]$, and cement as substitutes of fine aggregate $[18,19]$. 
Although these applications simultaneously treat waste and avoid environmental pollution derived from cement production, they cannot resolve the problem of heavy metal leaching $[20,21]$. Some new and improved technologies, such as thermal treatmentleaching [22,23], reduction-magnetic separation [24], sulfidation-flotation [25], acid decomposition-leaching [26], and sulphuric acid roasting-leaching [1], were developed to extract heavy metals. However, these technologies could be uneconomic in the case of low valuable metal contents in jarosite residues. Recently, some researchers have made great efforts to prepare functional materials from jarosite residues, such as cathode materials [27], photocatalysis [28], and adsorbents [29,30]. However, jarosite residues and the modified materials are often used in waste gas and heavy metal-bearing wastewater treatments.

Thermal treatment is a popular method for the modification of jarosite residues. It has been proven that natural natrojarosite $\left(\mathrm{NaFe}_{3}\left(\mathrm{SO}_{4}\right)_{2}(\mathrm{OH})_{6}\right)$ can transform to hematite at $500-550{ }^{\circ} \mathrm{C}$ under atmospheric conditions [31,32]. Wang et al. [33] suggested that hematite shows excellent desulfurization performance and can transform to pyrrhotite at temperatures above $600{ }^{\circ} \mathrm{C}$ and when in an $\mathrm{H}_{2} \mathrm{~S}$ atmosphere. As for pyrrhotite, previous studies have shown that pyrrhotite prepared by natural pyrite has good application potential in the treatment of heavy metal-polluted water [34,35]. Studies have also shown that monoclinic pyrrhotite (M-Po) exhibits more excellent adsorption performance than hexagonal pyrrhotite $(\mathrm{H}-\mathrm{Po})$ on account of more abundant pores on the surface and more vacancy points in the crystalline structure for M-Po nanoparticles [36,37]. Thus, these studies inspired us to consider that jarosite residues could be favorable raw materials for the preparation of $\mathrm{M}-\mathrm{Po}$, which can be used for removing heavy metals from aqueous water.

This work attempted to (1) prepare M-Po by using jarosite residues and $\mathrm{H}_{2} \mathrm{~S}$-containing industrial waste gas as raw materials and (2) evaluate the performance of M-Po in $\mathrm{Zn}$ and $\mathrm{Pb}$ removal from aqueous water. The objectives of this study were to (1) clarify mineral evolution during thermal Decomposition of jarosite residue in $\mathrm{H}_{2} \mathrm{~S}$ atmosphere, (2) explore the optimal technological conditions of preparing M-Po from jarosite residues, and (3) evaluate the heavy metal removal abilities of M-Po. This work is of great significance in treating jarosite residues, industrial waste gases, and wastewater synchronously.

\section{Materials and Methods}

\subsection{Sample Setting}

Fresh jarosite residues produced by zinc hydrometallurgy were collected from the Jiuhua Smelting Plant (Chizhou City, Anhui Province, China). The sample was crushed through a 200 mesh sieve with a sieve size of $0.075 \mathrm{~mm}$, and a pale yellow solid powder with a particle size of about $19 \mu \mathrm{m}$ was obtained. The chemical compositions of the jarosite residues were determined by X-ray fluorescence (XRF) spectroscopy. The results showed that jarosite residues contain (wt\%) mainly of Fe (43.33) and S (33.2), and less of $\mathrm{Zn}(2.27)$, $\mathrm{Si}(1.61), \mathrm{Na}(0.61), \mathrm{Ca}(0.61), \mathrm{Mn}(0.20), \mathrm{Pb}(0.14)$, and $\mathrm{Cu}(0.11)$. The X-ray diffraction (XRD) analysis showed that jarosite residues were composed mainly of natrojarosite (PDF: 36-0425), franklinite ( $\mathrm{FeZn}_{2} \mathrm{O}_{4}$, PDF: 22-1012), and gunningite ( $\mathrm{ZnSO}_{4}$, PDF: 08-0491) (Figure 1).

\subsection{Reaction Apparatus and Experiments}

Sulfidation experiments were conducted in a tube furnace where the reactor is a quartz tube (6 $\mathrm{mm}$ inner diameter) containing a quartz cotton supporting layer (Figure 2). Before heating, the $0.2 \mathrm{~g}$ pretreated sample was placed on the supporting layer and the tube was placed in the constant temperature zone of the tube furnace. The reaction apparatus was then heated in a nitrogen atmosphere at a heating rate of $5^{\circ} \mathrm{C} / \mathrm{min}$. When the anticipated temperature was achieved, the temperature was maintained constant, and the atmosphere was switched from $\mathrm{N}_{2}$ to mixed gas $\left(3 \% \mathrm{H}_{2} \mathrm{~S}\right.$ and $\left.97 \% \mathrm{~N}_{2}\right)$, which was controlled by a mass flow controller (D07-19BM, China). During the experiment, the outlet gas was collected to determine the $\mathrm{H}_{2} \mathrm{~S}$ concentration. A gas-phase molecular absorption spectrometer (GMA-3366, China) was used for $\mathrm{H}_{2} \mathrm{~S}$ measurement. The residual gas was exhausted by 
multistage absorption with a $5 \% \mathrm{NaOH}$. Sulfidation parameters, including temperature, time, and gas speed were investigated. Under a sulfidation time of $1.5 \mathrm{~h}$ and a gas speed of $40 \mathrm{~mL} / \mathrm{min}$, the temperatures were set to $100,200,300,400,500,525,550,575$, and $600{ }^{\circ} \mathrm{C}$. Under sulfidation temperatures of $525-600^{\circ} \mathrm{C}$ and a gas speed of $40 \mathrm{~mL} / \mathrm{L}$, the times were set to $0.5,1.0,1.5$, and $2 \mathrm{~h}$. Under sulfidation, a temperature of $575{ }^{\circ} \mathrm{C}$ and a time of $1.5 \mathrm{~h}$, gas speeds were set to $10,20,30$, and $40 \mathrm{~mL} / \mathrm{min}$.

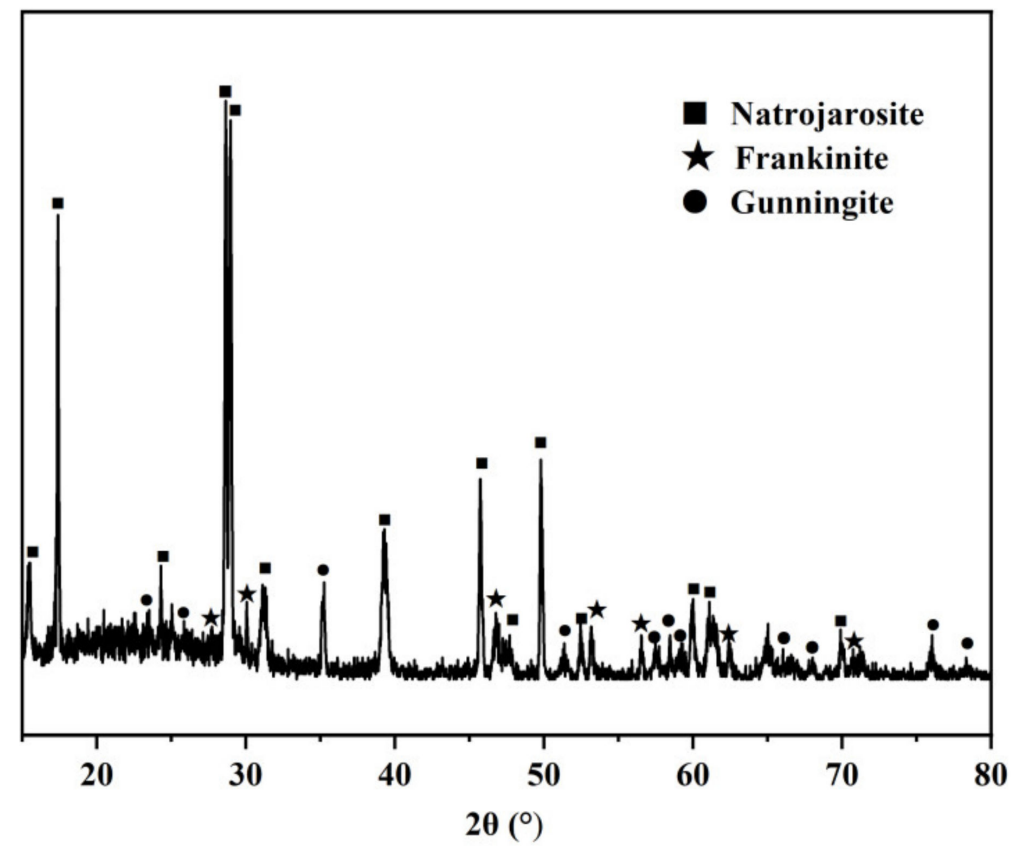

Figure 1. XRD pattern of jarosite residue.

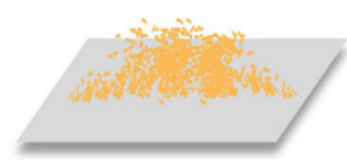

Jarosite residue

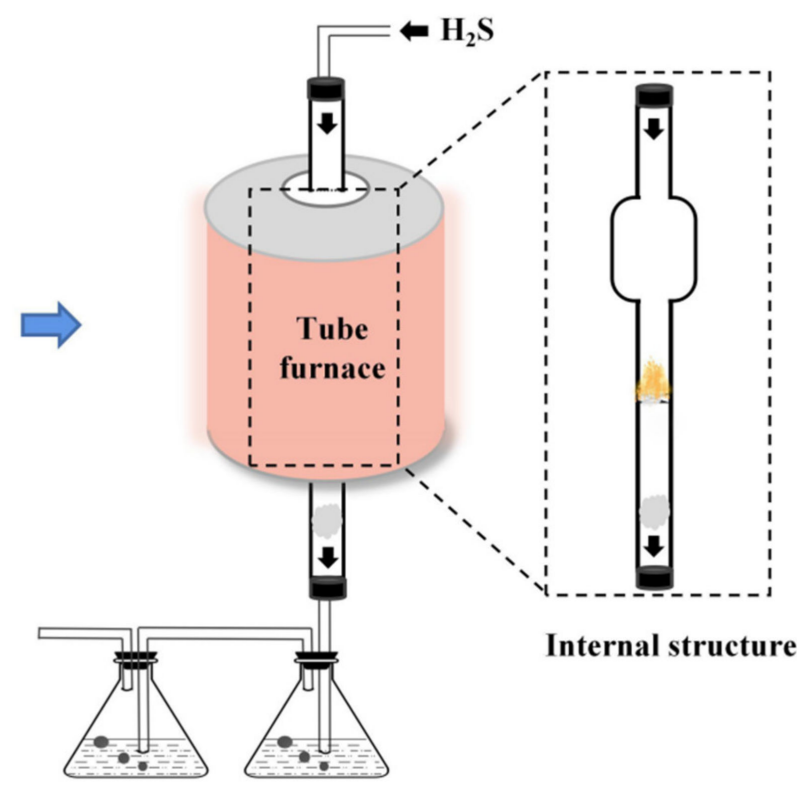

Adsorption bottles

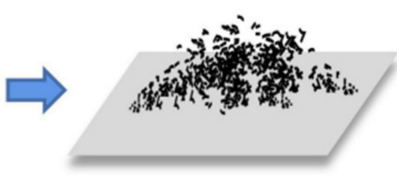

Sulfidation product

Figure 2. Sketch of the sulfidation device. 
The enrichment performances of $\mathrm{Zn}$ and $\mathrm{Pb}$ by sulfidation products were studied. Experiments were conducted in $100 \mathrm{~mL}$ polyethylene vessels, where each vessel contained $50 \mathrm{~mL} \mathrm{Zn}$ solution and $0.01 \mathrm{~g}$ sulfidation product, and the same solid-to-liquid ratio for the $\mathrm{Pb}$ solution. The initial $\mathrm{Zn}$ and $\mathrm{Pb}$ concentrations were set to 2, 5, 10, 20, 40, 80, 100, and $200 \mathrm{mg} / \mathrm{L}$, and the experimental temperature was set to $25^{\circ} \mathrm{C}$. The ionic strength $(\mathrm{NaCl}$ for $\mathrm{Zn}$ solution and $\mathrm{NaNO}_{3}$ for $\mathrm{Pb}$ solution) and $\mathrm{pH}$ were set to $0.01 \mathrm{M}$ and 5 , respectively. Experimental vessels were shaken continuously at a constant temperature in the shaker for $24 \mathrm{~h}$. After the reaction, the solution was extracted, centrifuged, and filtrated to obtain the supernatant, which was then analyzed by a flame atomic absorption spectrometry (WYS2200, China) to obtain the residual concentration of $\mathrm{Zn}$ or Pb. Each experiment was repeated three times. The removal efficiency $(\mathrm{Re})$ of $\mathrm{Zn}$ and $\mathrm{Pb}$ was estimated as:

$$
\operatorname{Re}=\left[\left(\mathrm{C}_{0}-\mathrm{C}_{\mathrm{e}}\right) / \mathrm{C}_{0}\right] \times 100
$$

where $\mathrm{C}_{0}$ and $\mathrm{C}_{\mathrm{e}}(\mathrm{mg} / \mathrm{L})$ are the initial and equilibrium concentrations of $\mathrm{Zn}$ and $\mathrm{Pb}$, respectively.

\subsection{Analytical Methods}

The chemical compositions of the raw jarosite residues were determined by an XRF spectrometer (XRF-1800, Shimadzu, Japan). The mineral species for jarosite residues before and after sulfidation were identified by a DS-2700 (Haoyuan, Dandong, China) XRD. The analysis conditions were: $\mathrm{Cu}-\mathrm{K} \alpha, 40 \mathrm{kV}, 30 \mathrm{~mA}$, and scanning rate $2^{\circ} / \mathrm{min}$. The valence states of $S$ in samples before and after sulfidation were determined by an ESCALAB 250Xi (Thermo Fisher Scientific, Waltham, MA, USA) XPS. The morphological characteristics of the minerals in samples before and after sulfidation were observed by a ZEISS Gemini 500 scanning electron microscope (SEM) (ZEISS, Thornwood, NY, USA).

\section{Results and Discussion}

\subsection{Determination of Optimal Sulfidation Conditions}

\subsubsection{Effect of Reaction Temperature}

Figure 3a shows that temperature is an important parameter on the Decomposition and sulfidation performance of jarosite residues. Diffraction peaks corresponding to natrojarosite were present for experiments at temperatures of $<300{ }^{\circ} \mathrm{C}$. Diffraction peaks corresponding to pyrite were present for experiments at $300-500{ }^{\circ} \mathrm{C}$. At $525^{\circ} \mathrm{C}$, both pyrite and pyrrhotite were present. For experiments at temperatures of $>525^{\circ} \mathrm{C}$, only pyrrhotite is present. Peaks in Figure 3a that are assigned to lattice planes of (203) and (206) of M-Po are enlarged in Figure $3 c$, respectively. Both peaks show an obvious left shift with increasing temperature, indicating the transformation of M-Po to H-Po. XRD results show that the lowest transformation temperature of natrojarosite to iron sulfide is in the range of $200-300{ }^{\circ} \mathrm{C}$. These results are in accordance with $\mathrm{H}_{2} \mathrm{~S}$ data $\left(\mathrm{C} / \mathrm{C}_{0}\right)$ shown in Figure $3 \mathrm{~d}$. For 100 and $200{ }^{\circ} \mathrm{C}$ experiments, the $\mathrm{C} / \mathrm{C}_{0}$ values increased to a stable state rapidly, indicating no $\mathrm{H}_{2} \mathrm{~S}$ consumption and natrojarosite transformation under both temperature conditions. For the $300{ }^{\circ} \mathrm{C}$ experiment, the $\mathrm{C} / \mathrm{C}_{0}$ value increased steadily during the whole sulfidation process, indicating the sustained transformation of natrojarosite to iron sulfide. As the temperatures increased, the breakthrough times gradually decreased, shortening from about $3 \mathrm{~h}$ for the $300{ }^{\circ} \mathrm{C}$ experiment to less than $1 \mathrm{~h}$ for the $600{ }^{\circ} \mathrm{C}$ experiment. It is noticeable that even if the reaction had reached equilibrium, the concentration of $\mathrm{H}_{2} \mathrm{~S}$ in the outlet was still slightly lower than that in the intake. This could be due to the splitting of $\mathrm{H}_{2} \mathrm{~S}$ molecules at high temperatures [38]. Based on the relationships between phases and temperature, it can be roughly thought that the transformation route is natrojarosite $\rightarrow$ pyrite $\rightarrow \mathrm{M}-\mathrm{Po} \rightarrow \mathrm{H}-\mathrm{Po}$. 

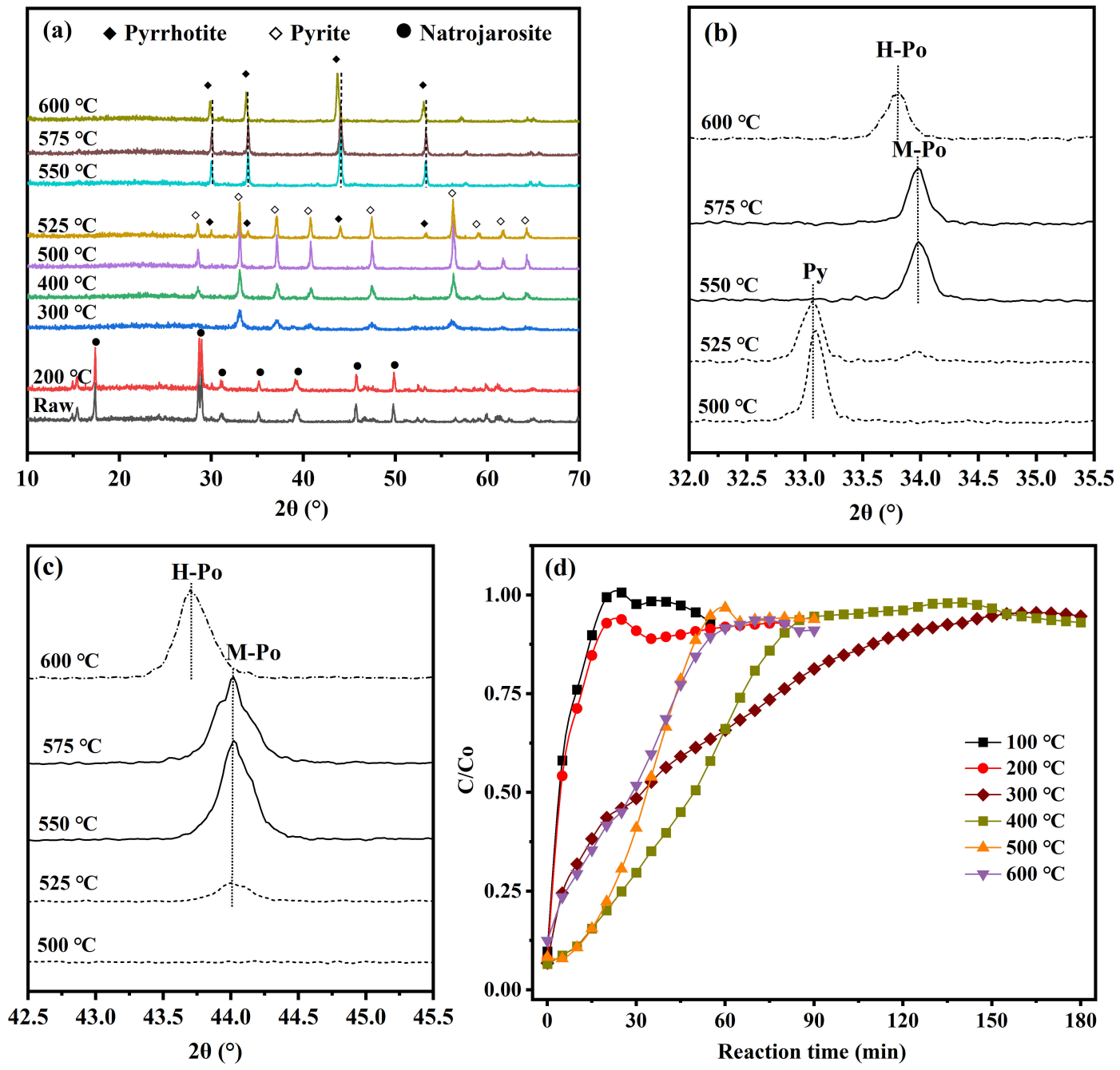

Figure 3. (a) XRD patterns of sulfidation products of jarosite residues under various temperatures (sulfidation conditions: 200-600 ${ }^{\circ} \mathrm{C}, 1.5 \mathrm{~h}, 40 \mathrm{~mL} / \mathrm{L}, 3 \% \mathrm{H}_{2} \mathrm{~S}$, and 97\% $\mathrm{N}_{2}$ balance gas); (b,c) partially enlarged areas of (a), where (b) corresponds to the lattice plane of (203) and (c) to the lattice plane of (206) of M-Po; (d) the breakthrough curves of $\mathrm{H}_{2} \mathrm{~S}\left(\mathrm{C}_{\text {and }} \mathrm{C}_{0}\right.$ are $\mathrm{H}_{2} \mathrm{~S}$ concentrations in effluent and initial gases, respectively).

\subsubsection{Effect of Reaction Time}

The above results show that pure pyrrhotite appears in a narrow temperature range $\left(550-600{ }^{\circ} \mathrm{C}\right)$. Thus, the temperatures of experiments that were set to investigate the effect of reaction time on sulfidation were 525, 550, 575, and $600{ }^{\circ} \mathrm{C}$. From Figure $4 \mathrm{a}$, it is observed that sulfidation time is not the controlling factor for phase assemblage. However, a detailed investigation shows that in the $600{ }^{\circ} \mathrm{C}$ experiment, peaks are at $43.7^{\circ}(2 \theta)$, which indicates the presence of H-Po increase in intensity with increasing sulfidation time (Figure $4 \mathrm{~b}$ ). This may indicate that at $600{ }^{\circ} \mathrm{C}$, the phase transformation is time-constrained. M-Po to H-Po transformation is a solid atomic rearrangement process; thus, it could be slow when the temperature is not high enough. One effective method to restrain the formation of H-Po is to reduce sulfidation time. However, it is not easy to determine the contents of M-Po and $\mathrm{H}-\mathrm{Po}$, as all the peaks are weak. It is noticed that in addition to $\mathrm{H}-\mathrm{Po}$, magnetite is present in the $600{ }^{\circ} \mathrm{C}$ and $0.5 \mathrm{~h}$ experiment (Figure $4 \mathrm{a}$ ). This may indicate a special transformation model, where electrons transfer into natrojarosite before $\mathrm{S}$, and thus, the inner part of a natrojarosite particle is transformed to magnetite instead of iron sulfide. 

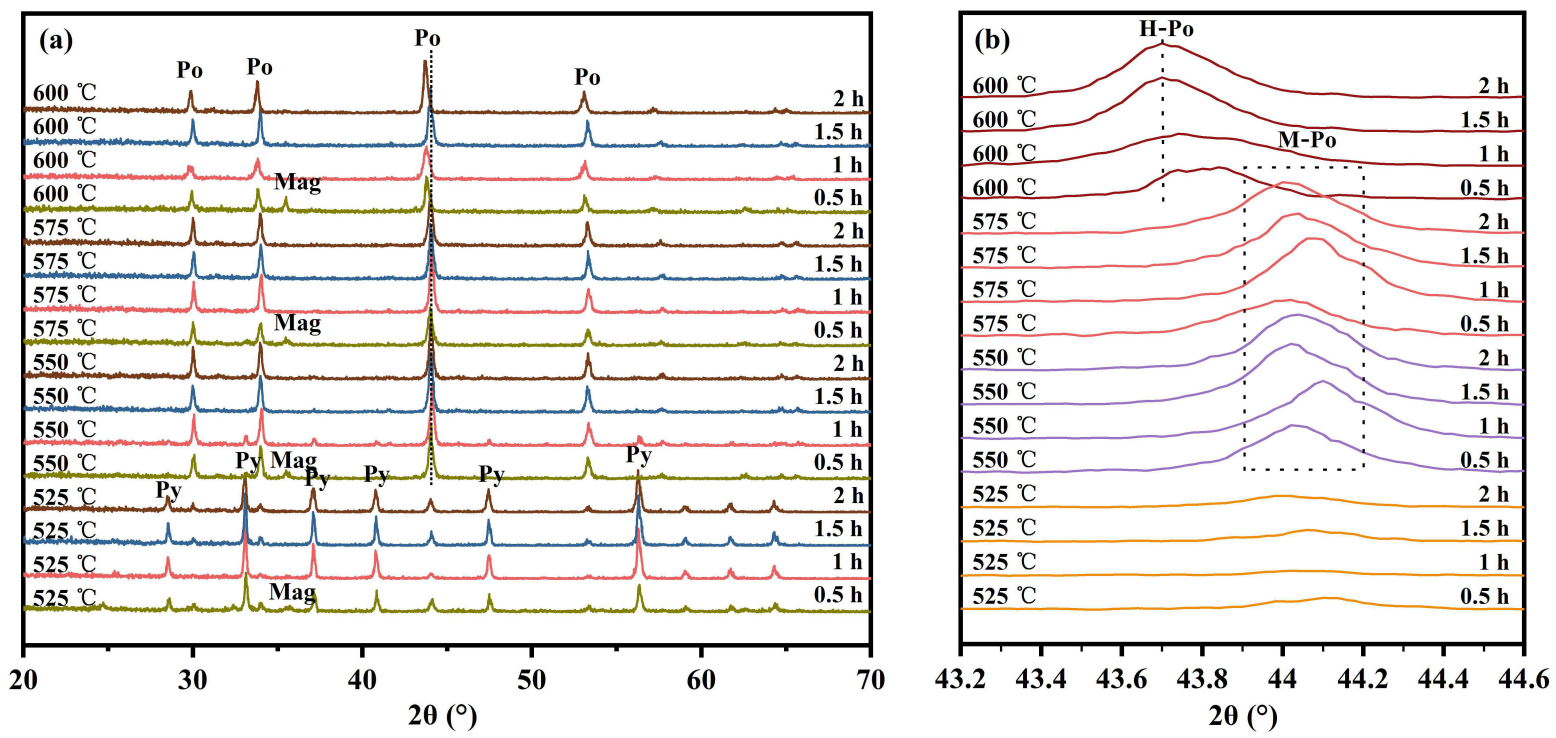

Figure 4. (a) XRD patterns of sulfidation products obtained under various temperatures and times (sulfidation conditions: $525-600{ }^{\circ} \mathrm{C}, 0.5-2 \mathrm{~h}, 40 \mathrm{~mL} / \mathrm{L}, 3 \% \mathrm{H}_{2} \mathrm{~S}$ and $97 \% \mathrm{~N}_{2}$ balance gas); (b) partially enlarged areas (20: 43.2-44.6 $\left.6^{\circ}\right)$ of $(\mathbf{a})$.

Under the other three temperature conditions, no H-Po is observed, even for $2 \mathrm{~h}$ experiments. For 550 and $575{ }^{\circ} \mathrm{C}$ experiments, a tendency of reaction time-induced increase and decrease in peak intensities is observed (Figure $4 \mathrm{~b}$ ). The increase in peak strength probably indicates the increase in the crystallinity of $\mathrm{M}-\mathrm{Po}$, while the decrease in peak strength may be attributed to the sintering of M-Po. It is suggested that the optimal conditions for preparing M-Po are $550-575{ }^{\circ} \mathrm{C}$, and $1.0-1.5 \mathrm{~h}$.

\subsubsection{Effect of Gas Speed}

Gas speed is an important parameter in this study, as too-low gas speed may decrease sulfidation efficiency, while too-high gas speed may add more burden to gas treatment. Figure 5a shows the gas speed dependencies of sulfidation products. It can be seen that in addition to pyrrhotite, hematite $\left(\alpha \mathrm{Fe}_{2} \mathrm{O}_{3}\right)$ and milasaite $\left(\mathrm{FeSO}_{4}\right)$ are also present in experiments with a gas speed of $10 \mathrm{~mL} / \mathrm{min}$. Monophase $\mathrm{M}-\mathrm{Po}$ is observed in experiments with a gas speed of $20 \mathrm{~mL} / \mathrm{min}$ or more. Additionally, gas speed may have a positive effect on mineral crystallinity, as the peak intensities of pyrrhotite increase with increasing gas speed. Considering that lower crystalline M-Po may have a higher surface area $\left(33.78 \mathrm{~m}^{2} / \mathrm{g}\right)$ and active sites, it is suggested that the optimal gas speed is $20 \mathrm{~mL} / \mathrm{min}$.

\subsection{XPS}

XPS was used to investigate the chemical states of $S$ in jarosite residues and the sulfidation product. The results show that $\mathrm{S}$ mainly exists as sulfates in raw jarosite residues (Figure 6a). Combined with chemical composition data, $\mathrm{S}$ with binding energies of 168.9 and $170.0 \mathrm{eV}$ are attributed to ferrous sulfate (possibly $\mathrm{FeSO}_{4}$ ) and ferric sulfate (jarosite, $\left.\mathrm{Fe}_{2}\left(\mathrm{SO}_{4}\right)_{3}\right)$, respectively. The ratio of ferrous and ferric sulfates was estimated by the peak area, and the value is about 1.8. The XPS result of the sulfidation product shows that $\mathrm{S}$ is in $-2,-1,0,+4$, and +6 valences, which are attributed to pyrrhotite, pyrite, elemental sulfur, sulfite, and sulfate, respectively (Figure 6b) [39-41]. The peaks for transitional $S_{8}$ and sulfite are weak, indicating that their contents are low. From $S$ state analysis, it can be deduced that the transformation of jarosite residues to pyrrhotite is a multistage process, where $S$ is reduced step by step. Mineral assemblage in the sulfidation product is determined by many factors, including temperature, sulfidation time, gas speed, and sulfur supply. Combined with XRD patterns of transformation products obtained under various sulfidation 
conditions, the following sulfidation reaction route of jarosite residues can be speculated by XPS results: $\mathrm{NaFe}_{2}\left(\mathrm{SO}_{4}\right)_{2}(\mathrm{OH})_{6} \cdot \mathrm{nH}_{2} \mathrm{O} \rightarrow \mathrm{Fe}_{2}\left(\mathrm{SO}_{4}\right)_{3} \rightarrow \mathrm{Fe}_{2} \mathrm{O}_{3} / \mathrm{Fe}_{3} \mathrm{O}_{4} \rightarrow \mathrm{FeS}_{2} \rightarrow \mathrm{Fe}_{1-\chi} \mathrm{X}$.
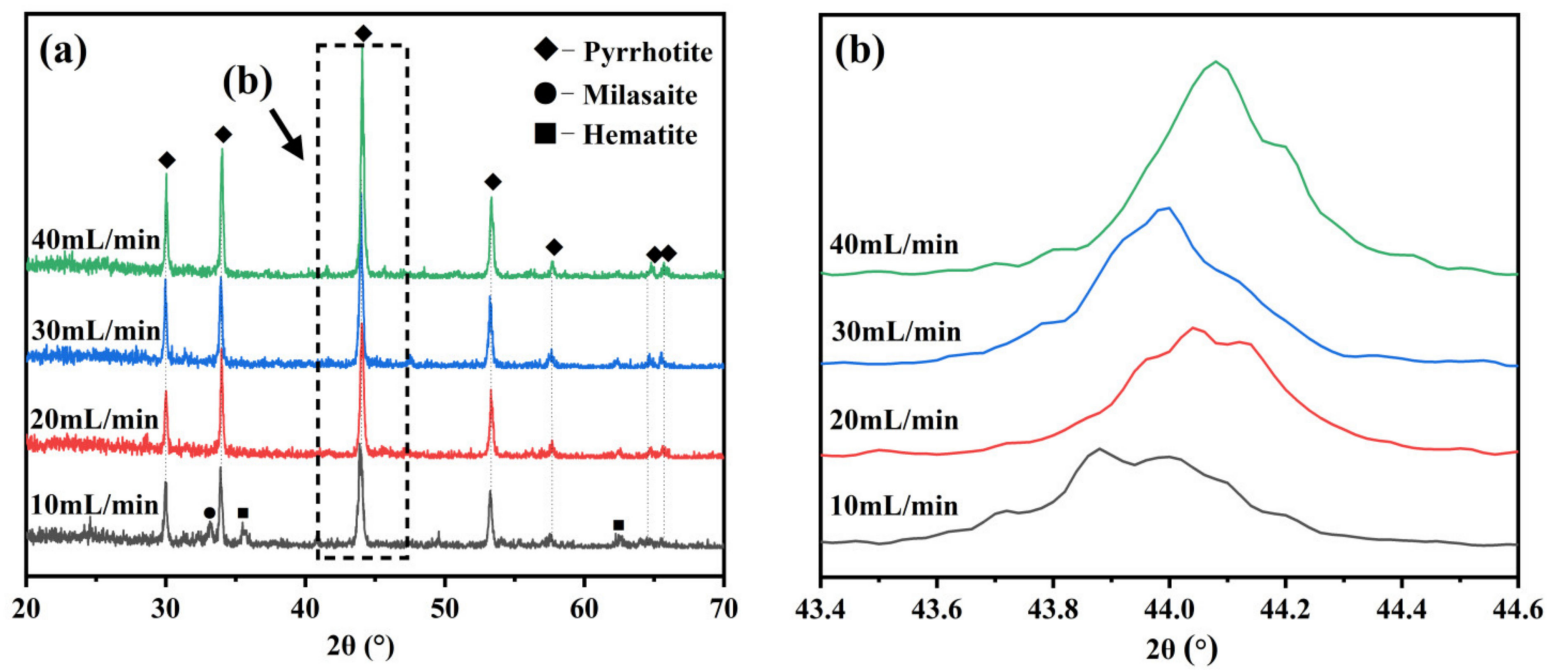

Figure 5. (a) XRD patterns of sulfidation products obtained under different gas speeds; (b) partially enlarged areas (20: 43.2-44.6 $6^{\circ}$ ) of (a) (sulfidation conditions: $575{ }^{\circ} \mathrm{C}, 1.5 \mathrm{~h}, 3 \% \mathrm{H}_{2} \mathrm{~S}$ and $97 \% \mathrm{~N}_{2}$ balance gas).
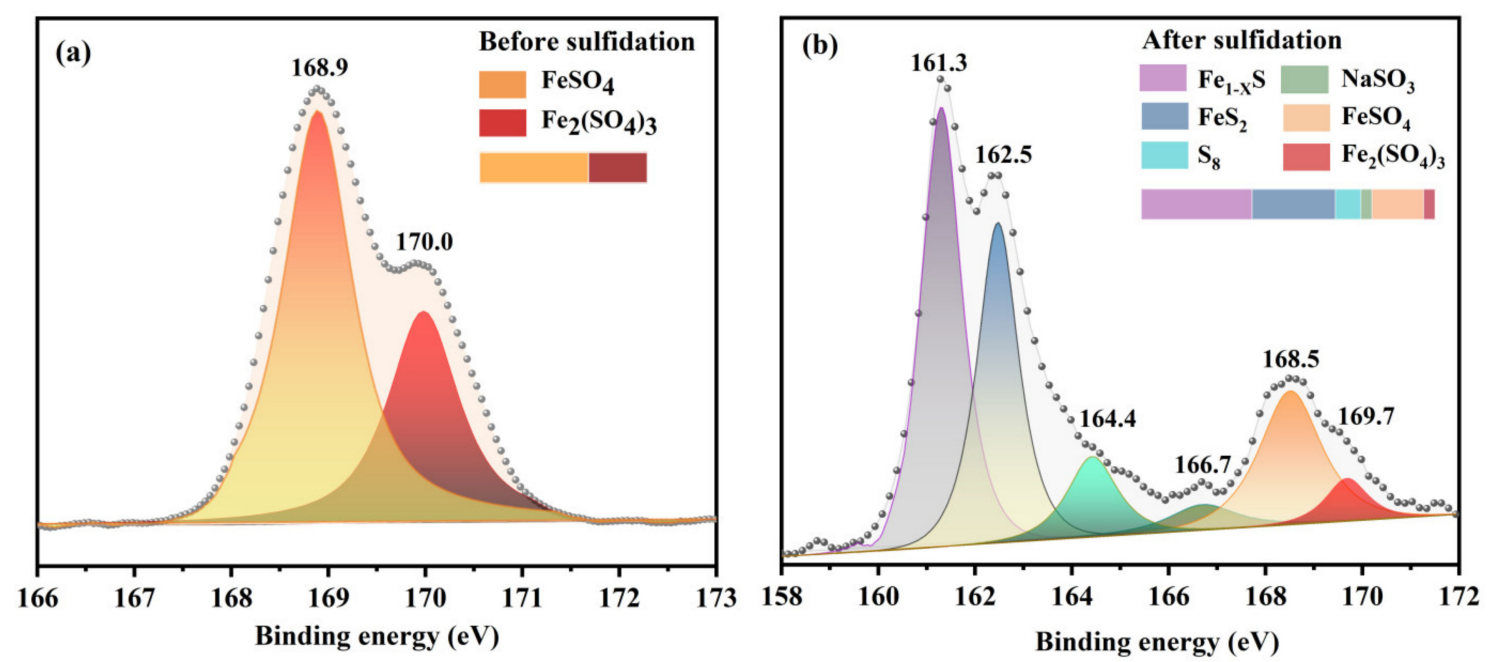

Figure 6. XPS spectra of $\mathrm{S} 2 \mathrm{p}$ for jarosite residues before (a) and after (b) sulfidation reaction (sulfidation conditions: $575{ }^{\circ} \mathrm{C}$, $1.5 \mathrm{~h}, 20 \mathrm{~mL} / \mathrm{min}, 3 \% \mathrm{H}_{2} \mathrm{~S}$ and $97 \% \mathrm{~N}_{2}$ balance gas).

\subsection{Mineral Morphology}

SEM micrographs show that euhedral crystals are the dominant natrojarosite forms in the raw jarosite residues (Figure 7a). A single euhedral natrojarosite crystal occurs as a plate shape with an average size of $2-10 \mu \mathrm{m}$. A higher magnification SEM image shows some aggregated attachments on the surface of natrojarosite particles (Figure $7 \mathrm{~b}$ ). Energy disperse spectroscopy measurement shows that they are composed of $\mathrm{Si}, \mathrm{Zn}, \mathrm{O}$, and $\mathrm{S}$, which indicates that $\mathrm{Zn}$ is mainly involved in nanosized sulfate mineral rather than in natrojarosite. For the sulfidation product at $500{ }^{\circ} \mathrm{C}$ (Figure 8a), it is observed that plateshaped euhedral natrojarosite crystals are replaced by nanosized particles. Additionally, some coarse particles are presented. Elemental mapping analysis indicated that the coarse particles are composed mainly of $\mathrm{Fe}$ and $\mathrm{O}$, while the fine particles are composed mainly of Fe and $S$ (Figure $8 b-d$ ). In association with XRD results, the coarse particles are considered 
to be iron oxides (hematite or magnetite), and the fine particles are pyrite. From the interfacial relationship that iron oxides are surrounded by pyrite, it is suggested that the sulfidation process can be divided into two stages: in the first stage, natrojarosite is transformed into iron oxides; in the second stage, $\mathrm{H}_{2} \mathrm{~S}$ reacts with iron oxides to form pyrite.
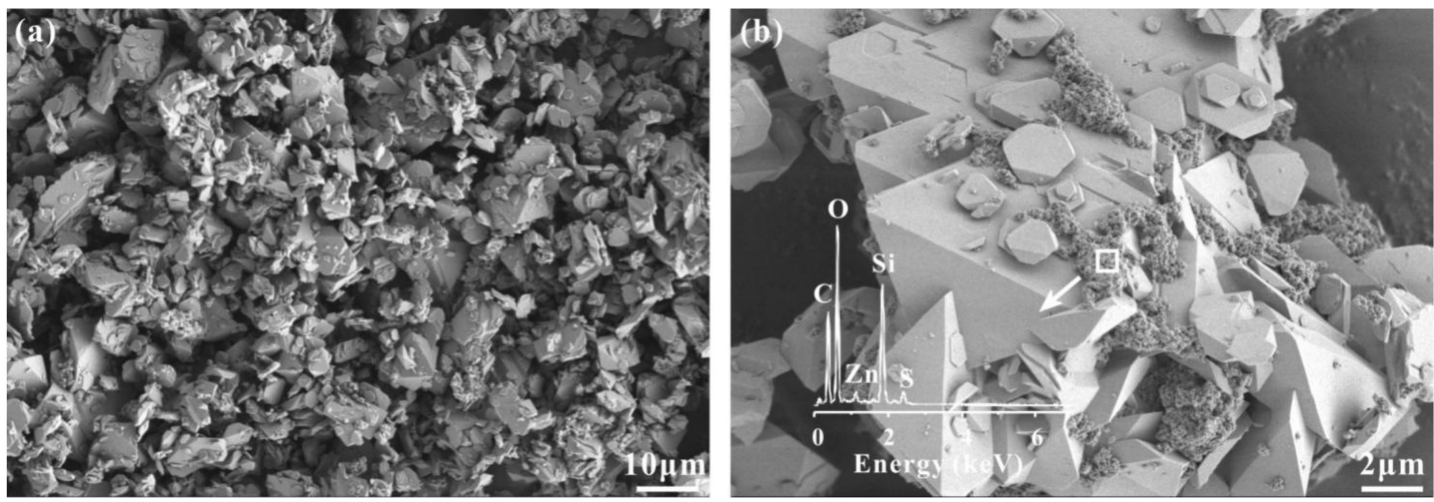

Figure 7. (a) SEM images of raw jarosite residues; (b) A higher magnification SEM image of raw jarosite residues and the EDS for elements within the white box.
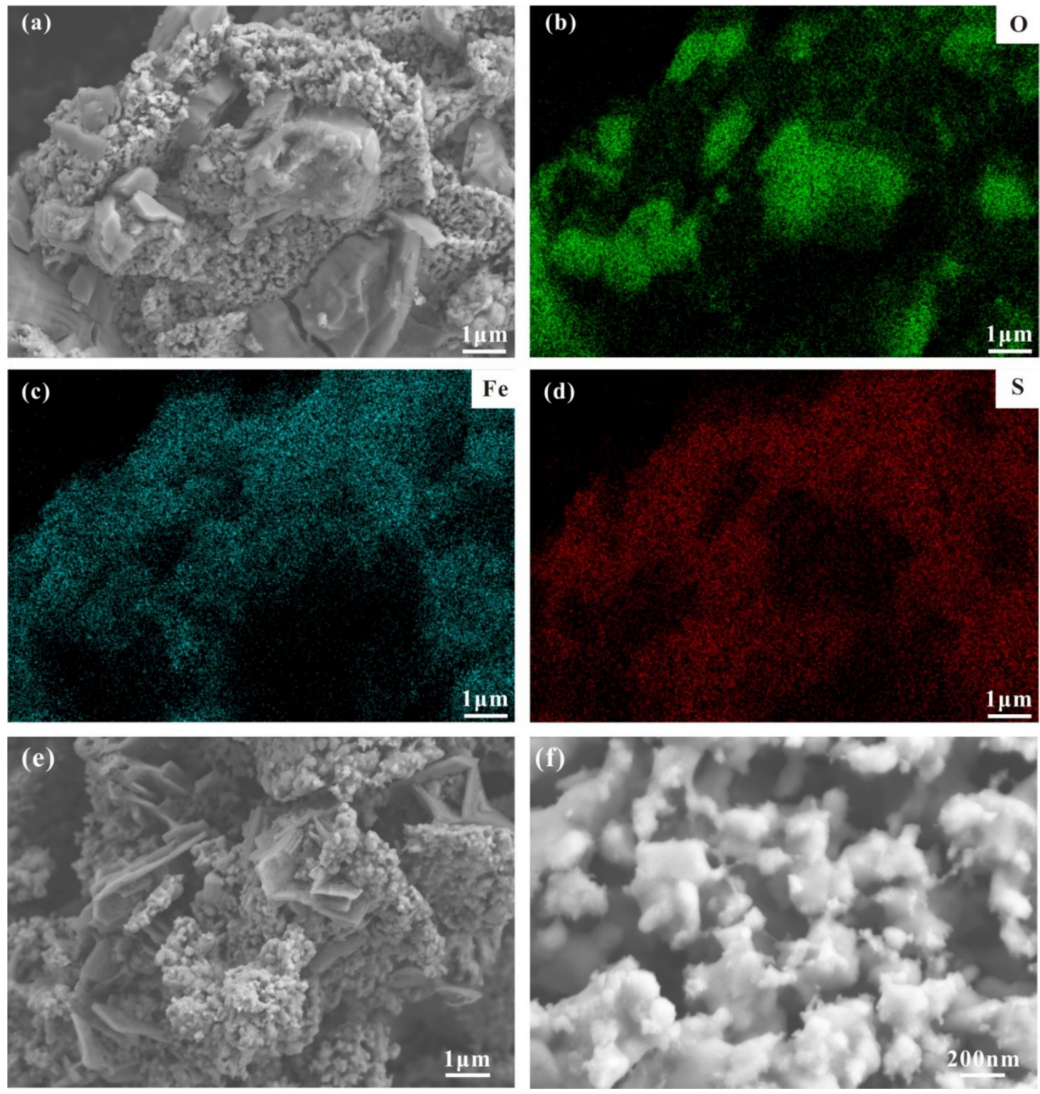

Figure 8. SEM images of a sulfidation product of jarosite residues: (a) sulfidation product at $500{ }^{\circ} \mathrm{C}$ for $1.5 \mathrm{~h}$; (b-d) element mappings of (a); (e,f) sulfidation product at $575^{\circ} \mathrm{C}$ for $1.5 \mathrm{~h}$.

The sulfidation product at $575{ }^{\circ} \mathrm{C}$ shows an obvious decrease in coarse particles and an increase in fine particles (Figure 8e). Unlike the granular shape that is observed for coarse particles in $500{ }^{\circ} \mathrm{C}$ pyrolyzed products, the coarse particles in the $575{ }^{\circ} \mathrm{C}$ pyrolyzed product are sheet-like. Elemental mapping analysis (not shown in Figure 8) indicated that they are iron oxides. The fine particles have a similar shape to those in $500{ }^{\circ} \mathrm{C}$ pyrolyzed product. However, the XRD result (Figure 3a) and the elemental mapping 
analysis (not shown in Figure 8) show that they are pyrrhotite instead of pyrite. In a higher magnification (Figure 8f), it is observed that the nanosized pyrrhotite particle is in irregular forms. The coexistence of iron oxides and pyrrhotite indicated that in addition to pyrite [42,43], iron oxides can also be the precursor of pyrrhotite. Hematite and magnetite, which are derived from dehydration and desulphurization of jarosite, react directly with $\mathrm{H}_{2} \mathrm{~S}$ to form pyrrhotite.

\subsection{Reaction Mechanism}

The XRD results show that natrojarosite is the dominant Fe source of sulfidation product. M-pyrrhotite is the target phase of sulfidation reaction. Based on systematic studies of mineralogy, sulfur states, and mineral morphology, the reaction process from natrojarosite to pyrrhotite in the $\mathrm{H}_{2} \mathrm{~S}$ atmosphere can be described by Equations (2)-(8), and by the model shown in Figure 9.

$$
\begin{gathered}
2 \mathrm{NaFe}_{3}\left(\mathrm{SO}_{4}\right)_{2}(\mathrm{OH})_{6}(\text { Natrojarosite }) \rightarrow 2 \mathrm{NaFe}\left(\mathrm{SO}_{4}\right)_{2}+2 \mathrm{Fe}_{2} \mathrm{O}_{3}(\mathrm{Hematite})+6 \mathrm{H}_{2} \mathrm{O} \\
2 \mathrm{NaFe}\left(\mathrm{SO}_{4}\right)_{2} \rightarrow \mathrm{Fe}_{2} \mathrm{O}_{3}(\text { Hematite })+3 \mathrm{SO}_{3}+\mathrm{Na}_{2} \mathrm{SO}_{4} \\
3 \mathrm{Fe}_{2} \mathrm{O}_{3}+\mathrm{H}_{2} \mathrm{~S} \rightarrow 2 \mathrm{Fe}_{3} \mathrm{O}_{4} \text { (Magnetite) }+\mathrm{S}+\mathrm{H}_{2} \mathrm{O} \\
\mathrm{Fe}_{2} \mathrm{O}_{3}+3 \mathrm{H}_{2} \mathrm{~S} \rightarrow \mathrm{Fe}_{1-x} \mathrm{~S}+\mathrm{FeS}_{2}+3 \mathrm{H}_{2} \mathrm{O} \\
\mathrm{Fe}_{3} \mathrm{O}_{4}+3 \mathrm{H}_{2} \mathrm{~S} \rightarrow \mathrm{FeS}_{2}(\mathrm{Pyrite})+2 \mathrm{Fe}_{1-\mathrm{x}} \mathrm{S}(\mathrm{M}-\mathrm{Po})+3 \mathrm{H}_{2} \mathrm{O} \\
(1-\mathrm{x}) \mathrm{FeS}_{2} \rightarrow \mathrm{Fe}_{1-\mathrm{x}} \mathrm{S}+\mathrm{S} \\
\mathrm{Fe}_{1-\mathrm{x}} \mathrm{S}(\mathrm{M}-\mathrm{Po}) \rightarrow \mathrm{Fe}_{1-\mathrm{x}} \mathrm{S}(\mathrm{H}-\mathrm{Po})
\end{gathered}
$$

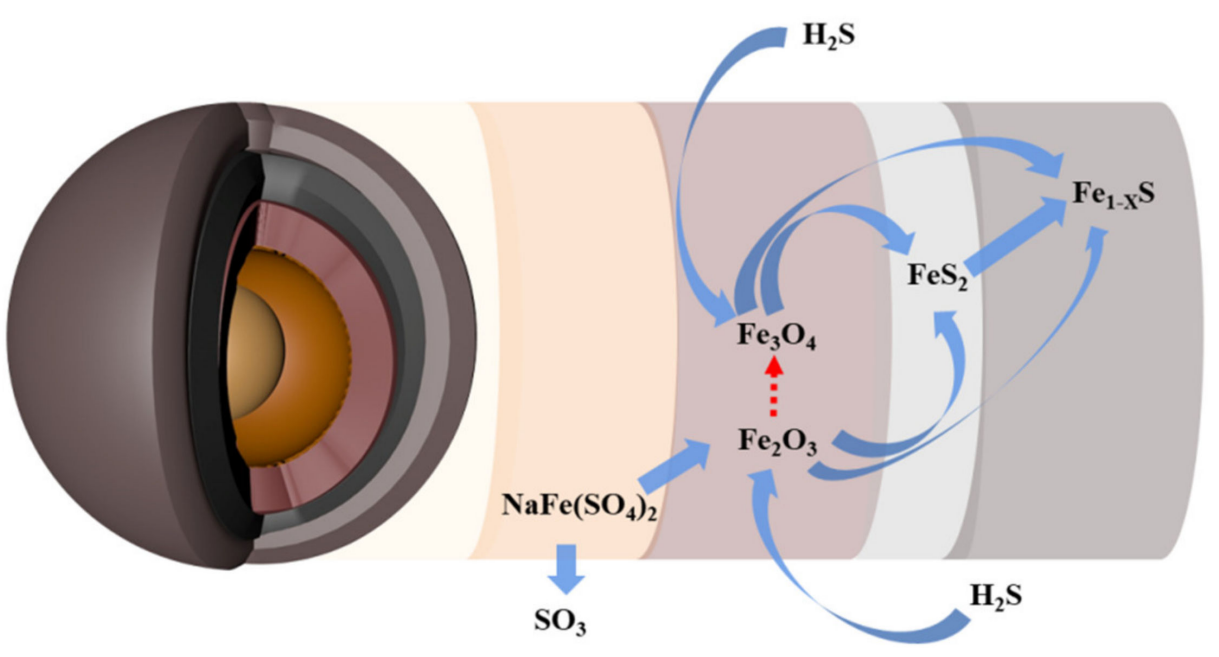

Figure 9. Sulfidation model of natrojarosite to iron sulfides.

At $200-300{ }^{\circ} \mathrm{C}$, dehydration is the main reaction, where natrojarosite is thermally transformed into $\mathrm{NaFe}_{2}\left(\mathrm{SO}_{4}\right)_{3}$ and hematite (Equations (2) and (3)) [44]. The release of $\mathrm{SO}_{3}$ can lead to the formation of a pore structure, which could promote the water treatment effect of the sulfidation product. At a temperature of $\geq 300^{\circ} \mathrm{C}$ and under $\mathrm{H}_{2} \mathrm{~S}$ condition, the newly formed hematite is transformed into magnetite, pyrite, and probably pyrrhotite (Equations (4) and (5)) [45]. Magnetite can be further transformed into pyrite and pyrrhotite (Equation (6)). In this stage, the reaction temperature and gas speed of $\mathrm{H}_{2} \mathrm{~S}$ constrain the reaction rates and the species of iron oxides. For coarse particles, a special structure with iron oxides core and iron sulfides rim can be easily formed. However, it is difficult to identify iron oxides, or even iron sulfate, as they are encapsulated by iron sulfides and their contents are low. 
As the reaction temperature increases to $550{ }^{\circ} \mathrm{C}$, abundant M-Po begins to form. Pyrite and M-Po coexist in the sulfidation product (Figure $3 b$ ). M-Po may be formed through the sulfidation of hematite (Equation (6)), magnetite (Equations (5) and (6)), and the Decomposition of pyrite (Equation (7)). At above $525^{\circ} \mathrm{C}$, pyrite to M-Po transformation could be the main process. At reaction temperature $\geq 600^{\circ} \mathrm{C}$, partial M-Po is transformed to $\mathrm{H}-\mathrm{Po}$. Based on the analysis of the mineral evolution pathway, it was found that sulfidation of jarosite residues at $300-500{ }^{\circ} \mathrm{C}$ can remove $\mathrm{H}_{2} \mathrm{~S}$, which thus is a favorable technology to simultaneously treat jarosite residues and $\mathrm{H}_{2} \mathrm{~S}$-contained smokes. Moreover, sulfidation of jarosite residues at $550-600^{\circ} \mathrm{C}$ can prepare magnetic nanometer material (M-Po), which could be useful in water treatment. As a byproduct of sulfidation reaction, $\mathrm{SO}_{3}$ could be precipitated by a Ca solution to form gypsum.

\subsection{Removal Efficiencies of $\mathrm{Zn}$ and $\mathrm{Pb}$ by Sulfidation Product}

Figure 10 shows that under experimental conditions $\left(0.2 \mathrm{~g} / \mathrm{L}, 25^{\circ} \mathrm{C}, 6 \mathrm{~h}, \mathrm{Ph}=5\right)$, the sulfidation product has an excellent removal ability for $\mathrm{Zn}$ and $\mathrm{Pb}$. The adsorption capacities for $\mathrm{Zn}$ and $\mathrm{Pb}$ are 25 and $100 \mathrm{mg} / \mathrm{g}$, respectively. The adsorption capacity of other adsorbents for the removal of $\mathrm{Zn}$ and $\mathrm{Pb}$ from aqueous phase is given in Tables 1 and 2 for comparison. According to XRD and SEM analyses (Figures 3 and 8), M-Po is not only the dominant phase in the sulfidation product but also shows a very small particle size. Thus, there is no doubt that $\mathrm{Zn}$ and $\mathrm{Pb}$ are removed by $\mathrm{M}-\mathrm{Po} . \mathrm{Zn}$ and $\mathrm{Pb}$ are two elements that are often involved in jarosite residues. Thus, M-Po-dominant sulfidation product could play crucial roles in metallurgy; on the one hand, heavy metals can be retained and enriched in M-Po during sulfidation, while on the other hand, M-Po can be used to enrich and recover valuable metals from waste gases and waters. From an environmental point of view, the M-Po-dominant sulfidation product is a potential water treatment material that can be used for eliminating heavy metals.

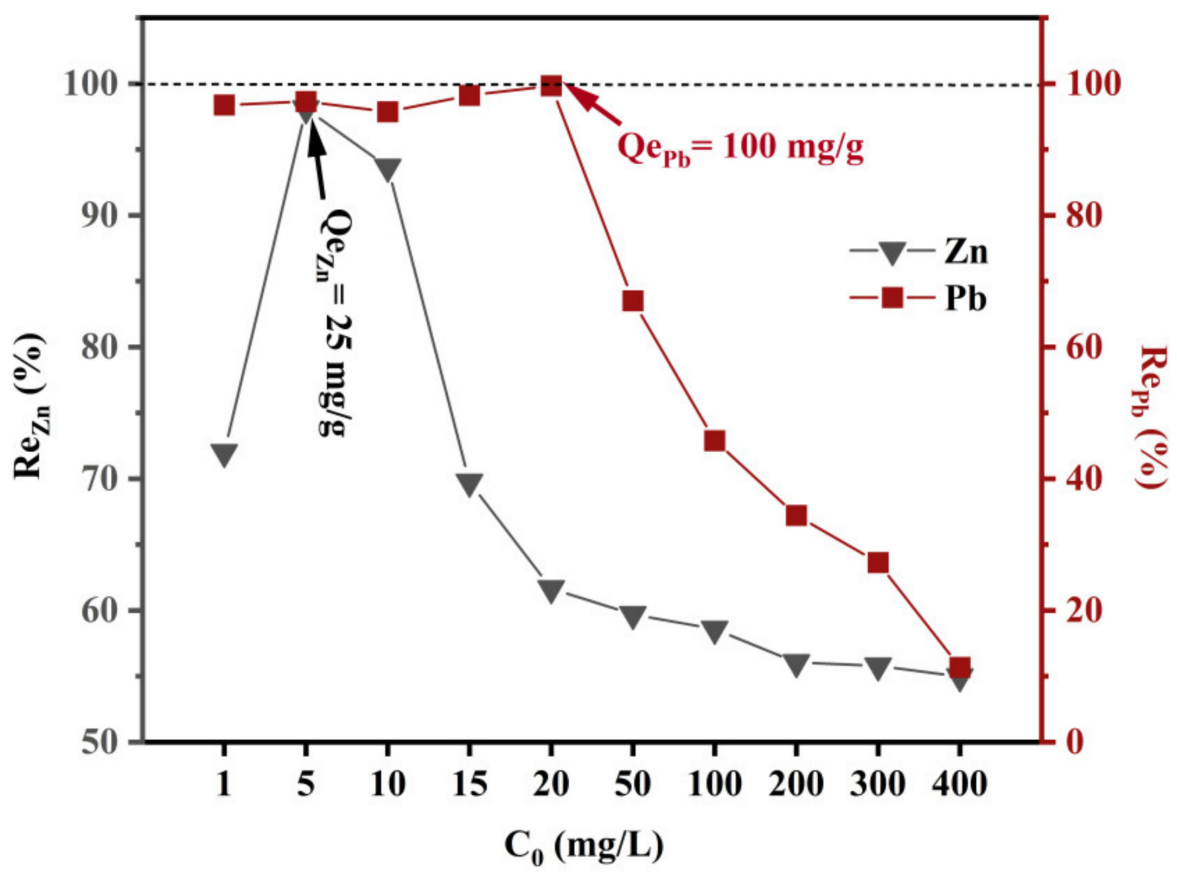

Figure 10. Removal efficiencies of $\mathrm{Zn}$ and $\mathrm{Pb}$ from aqueous solution by sulfidation product (reaction conditions: solid-to-liquid ratio $0.2 \mathrm{~g} / \mathrm{L}, 25^{\circ} \mathrm{C}, 6 \mathrm{~h}$ ). 
Table 1. Comparison of $\mathrm{Zn}$ removal with different adsorbents reported in the literature.

\begin{tabular}{ccc}
\hline Adsorbent & Adsorption Capacities of $\mathbf{Z n ~ ( m g / g ) ~}$ & Reference \\
\hline Modified Carbon Nanofibers & 1.05 & {$[46]$} \\
$\gamma \mathrm{Al}_{2} \mathrm{O}_{3}$ & 7.60 & {$[47]$} \\
Hematite nanoparticles & 8.56 & {$[48]$} \\
Activated carbon & 22.03 & {$[49]$} \\
Pyrrhotite prepared by & 25.00 & This study \\
jarosite residues & & \\
\hline
\end{tabular}

Table 2. Comparison of $\mathrm{Pb}$ removal with different adsorbents reported in the literature.

\begin{tabular}{ccc}
\hline Adsorbent & Adsorption Capacities of $\mathbf{P b}(\mathbf{m g} / \mathbf{g})$ & Reference \\
\hline Composite material: & 10.64 & {$[50]$} \\
polystyrene/alumina/carbon & 13.11 & {$[47]$} \\
$\gamma \mathrm{Al}_{2} \mathrm{O}_{3}$ & 39.10 & {$[51]$} \\
Zeolite & 96.20 & {$[51]$} \\
Z-nZVI composite & 100 & This study \\
Pyrrhotite prepared by & & \\
jarosite residues & &
\end{tabular}

\section{Conclusions}

The jarosite residues as an industrial byproduct in refining and hydrometallurgical processes can be converted from $\mathrm{H}_{2} \mathrm{~S}$-contained industrial waste gas to a functional material with high-performance heavy metal removal. The phase evolution route of jarosite residues during sulfidation can be written as: jarosite $\rightarrow$ hematite/magnetite $\rightarrow$ pyrite $\rightarrow$ pyrite+monoclinic pyrrhotite $\rightarrow$ monoclinic pyrrhotite+hexagonal pyrrhotite $\rightarrow$ hexagonal pyrrhotite. The M-Po-dominant sulfidation product is formed mainly at $550-575{ }^{\circ} \mathrm{C}$. The M-Po-dominant sulfidation product is a high-performance material for removing $\mathrm{Zn}$ and $\mathrm{Pb}$ and probably other heavy metals from an aqueous solution. Thermal Decomposition of jarosite residues in the $\mathrm{H}_{2} \mathrm{~S}$ atmosphere has significance both in metallurgy and environmental engineering. In metallurgy, M-Po-dominant sulfidation products can enrich heavy metals both from jarosite residues and aqueous solutions. The enriched heavy metals can thus be recovered through the appropriate method. In environmental engineering, the MPo-dominant sulfidation product is a potential material for treating heavy metal-polluted gases and waters.

Author Contributions: Y.Z. and Q.X. conceived the study and designed the experiments; C.X., F.X., and H.W. conducted the experiments and produced the figures; C.X. and Y.Z. wrote the paper; Q.X., T.C., and S.P. edited the paper. All authors have read and agreed to the published version of the manuscript.

Funding: This research was funded by National Natural Science Foundation of China (41672038, 41872043).

Data Availability Statement: Data is contained within the article.

Acknowledgments: This work was supported by the National Natural Science Foundation of China (No. 41672038, 41872043). We thank Zhang Qiang from the Scanning Electron Microscopy Room of the Analysis and Testing Center of Hefei University of Technology.

Conflicts of Interest: The authors declare no conflict of interest.

\section{References}

1. Liu, C.; Ju, S.H.; Zhang, L.B.; Srinivasakannan, C.; Peng, J.H.; Le, T.Q.X.; Guo, Z.Y. Recovery of valuable metals from jarosite by sulphuric acid roasting using microwave and water leaching. Can. Metall. Q. 2016, 56, 1-9. [CrossRef]

2. Ju, S.-H.; Zhang, L.-B.; Peng, J.-H.; Shi, Z.; Guo, S.-H.; Liu, B.-G.; Wang, Y.-J. Thermodynamics of leaching roasted jarosite residue from zinc hydrometallurgy in $\mathrm{NH} 4 \mathrm{Cl}$ system. Trans. Nonferr. Met. Soc. China 2013, 23, 1179-1183. [CrossRef] 
3. Wang, F.; Yu, J.; Xiong, W.; Xu, Y.; Chi, R.-A. A two-step leaching method designed based on chemical fraction distribution of the heavy metals for selective leaching of $\mathrm{Cd}, \mathrm{Zn}, \mathrm{Cu}$, and $\mathrm{Pb}$ from metallurgical sludge. Environ. Sci. Pollut. Res. 2017, 25, 1752-1765. [CrossRef]

4. Dutrizac, J.E.; Chen, T.T. A Mineralogical Study of the Jarosite Phase Formed During the Autoclave Leaching of Zinc Concentrate. Can. Metall. Q. 1984, 23, 147-157. [CrossRef]

5. Elgersma, F.; Witkamp, G.; Van Rosmalen, G. Incorporation of zinc in continuous jarosite precipitation. Hydrometallurgy 1993, 33, 313-339. [CrossRef]

6. Kerolli-Mustafa, M.; Fajković, H.; Rončević, S.; Ćurković, L. Assessment of metal risks from different depths of jarosite tailing waste of Trepça Zinc Industry, Kosovo based on BCR procedure. J. Geochem. Explor. 2015, 148, 161-168. [CrossRef]

7. Islas, H.; Flores, M.U.; Reyes, I.A.; Juárez, J.C.; Reyes, M.; Teja, A.M.; Palacios, E.G.; Pandiyan, T.; Aguilar-Carrillo, J. Determination of the dissolution rate of hazardous jarosites in different conditions using the shrinking core kinetic model. J. Hazard. Mater. 2020, 386, 121664. [CrossRef]

8. Dong, Z.; Jiang, T.; Xu, B.; Yang, J.; Chen, Y.; Li, Q.; Yang, Y. Comprehensive recoveries of selenium, copper, gold, silver and lead from a copper anode slime with a clean and economical hydrometallurgical process. Chem. Eng. J. 2020, 393, 124762. [CrossRef]

9. Zhang, C.; Min, X.; Zhang, J.; Wang, M.; Li, Y.; Fei, J. Reductive clean leaching process of cadmium from hydrometallurgical zinc neutral leaching residue using sulfur dioxide. J. Clean. Prod. 2016, 113, 910-918. [CrossRef]

10. Calla-Choque, D.; Lapidus, G. Acid Decomposition and silver leaching with thiourea and oxalate from an industrial jarosite sample. Hydrometallurgy 2020, 192, 105289. [CrossRef]

11. Palden, T.; Regadio, M.; Onghena, B.; Binnemans, K. Selective Metal Recovery from Jarosite Residue by Leaching with AcidEquilibrated Ionic Liquids and Precipitation-Stripping. ACS Sustain. Chem. Eng. 2019, 7, 4239-4246. [CrossRef]

12. Mymrin, V.A.; Ponte, H.A.; Impinnisi, P.R. Potential application of acid jarosite wastes as the main component of construction materials. Constr. Build. Mater. 2005, 19, 141-146. [CrossRef]

13. Asokan, P.; Saxena, M.; Asolekar, S. Recycling hazardous jarosite waste using coal combustion residues. Mater. Charact. 2010, 61, 1342-1355. [CrossRef]

14. Asokan, P.; Saxena, M.; Asolekar, S.R. Hazardous jarosite use in developing non-hazardous product for engineering application. J. Hazard. Mater. 2006, 137, 1589-1599. [CrossRef] [PubMed]

15. Pappu, A.; Thakur, V.K.; Patidar, R.; Asolekar, S.R.; Saxena, M. Recycling marble wastes and Jarosite wastes into sustainable hybrid composite materials and validation through Response Surface Methodology. J. Clean. Prod. 2019, 240, 118249. [CrossRef]

16. Gupta, T.; Sachdeva, S.N. Investigations on Jarosite Mixed Cement Concrete Pavements. Arab. J. Sci. Eng. 2019, 44, 8787-8797. [CrossRef]

17. Gupta, T.; Sachdeva, S. Study of mechanical, micro-structural and environmental properties of concrete containing zinc industry waste for pavements. Constr. Build. Mater. 2020, 245, 118331. [CrossRef]

18. Isteri, V.; Ohenoja, K.; Hanein, T.; Kinoshita, H.; Tanskanen, P.; Illikainen, M.; Fabritius, T. Production and properties of ferrite-rich CSAB cement from metallurgical industry residues. Sci. Total Environ. 2020, 712, 136208. [CrossRef] [PubMed]

19. Mehra, P.; Gupta, R.C.; Thomas, B.S. Assessment of durability characteristics of cement concrete containing jarosite. J. Clean. Prod. 2016, 119, 59-65. [CrossRef]

20. Belebchouche, C.; Moussaceb, K.; Aït-Mokhtar, A. Evaluation of the encapsulation of nickel, chromium and lead-rich wastes in cement matrices by TCLP test. Eur. J. Environ. Civ. Eng. 2015, 20, 1-14. [CrossRef]

21. Benavente, D.; Pla, C.; Valdes-Abellan, J.; Cremades-Alted, S. Remediation by waste marble powder and lime of jarosite-rich sediments from Portman Bay (Spain). Environ. Pollut. 2020, 264, 114786. [CrossRef]

22. Linsong, W.; Peng, Z.; Yu, F.; SuJun, L.; Yue, Y.; Li, W.; Wei, S. Recovery of metals from jarosite of hydrometallurgical nickel production by thermal treatment and leaching. Hydrometallurgy 2020, 198, 105493. [CrossRef]

23. Rämä, M.; Nurmi, S.; Jokilaakso, A.; Klemettinen, L.; Taskinen, P.; Salminen, J. Thermal Processing of Jarosite Leach Residue for a Safe Disposable Slag and Valuable Metals Recovery. Metals 2018, 8, 744. [CrossRef]

24. Wang, Y.-Y.; Yang, H.-F.; Jiang, B.; Song, R.-L.; Zhang, W.-H. Comprehensive recovery of lead, zinc, and iron from hazardous jarosite residues using direct reduction followed by magnetic separation. Int. J. Miner. Met. Mater. 2018, 25, 123-130. [CrossRef]

25. Han, H.; Sun, W.; Hu, Y.; Jia, B.; Tang, H. Anglesite and silver recovery from jarosite residues through roasting and sulfidizationflotation in zinc hydrometallurgy. J. Hazard. Mater. 2014, 278, 49-54. [CrossRef]

26. Calla-Choque, D.; Nava-Alonso, F.; Fuentes-Aceituno, J. Acid Decomposition and thiourea leaching of silver from hazardous jarosite residues: Effect of some cations on the stability of the thiourea system. J. Hazard. Mater. 2016, 317, 440-448. [CrossRef]

27. Chang, L.; Wang, Y.; Luo, S.; Liu, H.; Wang, Q. Carbothermal reduction preparation and performance of LiFePO4/C by using ammonium jarosite extracted from vanadium slag as iron source. Ionics 2019, 25, 5725-5734. [CrossRef]

28. Xu, Z.; Liang, J.; Zhou, L. Photo-Fenton-like degradation of azo dye methyl orange using synthetic ammonium and hydronium jarosite. J. Alloy. Compd. 2013, 546, 112-118. [CrossRef]

29. Hu, H.; Lin, C.; Zhang, Y.; Cai, X.; Huang, Z.; Chen, C.; Qin, Y.; Liang, J. Preparation of a Stable Nanoscale Manganese Residue-Derived FeS@Starch-Derived Carbon Composite for the Adsorption of Safranine T. Nanomaterials 2019, 9, 839. [CrossRef] [PubMed]

30. Meng, X.; Zhang, C.; Zhuang, J.; Zheng, G.; Zhou, L. Assessment of schwertmannite, jarosite and goethite as adsorbents for efficient adsorption of phenanthrene in water and the regeneration of spent adsorbents by heterogeneous fenton-like reaction. Chemosphere 2020, 244, 125523. [CrossRef] [PubMed] 
31. Drouet, C.; Navrotsky, A. Synthesis, characterization, and thermochemistry of K-Na- $\mathrm{H}_{3} \mathrm{O}$ jarosites. Geochim. Cosmochim. Acta 2003, 67, 2063-2076. [CrossRef]

32. Flores, M.U.; Reyes, I.A.; Palacios, E.G.; Patiño, F.; Juárez, J.C.; Reyes, M.; Teja, A.M.; Islas, H.; Gutiérrez, E.J. Kinetic Analysis of the Thermal Decomposition of a Synthetic Mercury Jarosite. Minerals 2019, 9, 200. [CrossRef]

33. Wang, H.; Chen, T.; Liu, H.; Li, W.; Zou, X.; Wang, C.; Li, M. Comprehensive Application of Oolitic Hematite for H2S Removal at High Temperature: Performance and Mechanism. Energy Fuels 2019, 33, 2037-2044. [CrossRef]

34. Chen, T.; Yang, Y.; Li, P.; Liu, H.; Xie, J.; Xie, Q.; Zhan, X. Performance and characterization of calcined colloidal pyrite used for copper removal from aqueous solutions in a fixed bed column. Int. J. Miner. Process. 2014, 130, 82-87. [CrossRef]

35. Yang, Y.; Chen, T.; Li, P.; Xie, Q.; Zhan, X. Cu Removal from Acid Mine Drainage by Modified Pyrite: Batch and Column Experiments. Mine Water Environ. 2016, 36, 371-378. [CrossRef]

36. Lu, P.; Chen, T.; Liu, H.; Li, P.; Peng, S.; Yang, Y. Green Preparation of Nanoporous Pyrrhotite by Thermal Treatment of Pyrite as an Effective $\mathrm{Hg}(\mathrm{II})$ Adsorbent: Performance and Mechanism. Minerals 2019, 9, 74. [CrossRef]

37. Zhu, Y.; Peng, S.; Lu, P.; Chen, T.; Yang, Y. Mercury Removal from Aqueous Solutions Using Modified Pyrite: A Column Experiment. Minerals 2019, 10, 43. [CrossRef]

38. Zakarina, N.A.; Volkova, L.D.; Kim, O.K.; Brodskii, A.R.; Latypov, I.F.; Yaskevich, V.I.; Komashko, L.V. Natural iron-containing materials and catalysts on their basis on use for photocatalytic Decomposition of hydrogen sulfide. Pet. Chem. 2013, 53, 181-186. [CrossRef]

39. Herbert, F.; Krishnamoorthy, A.; Ma, W.; Van Vliet, K.; Yildiz, B. Dynamics of point defect formation, clustering and pit initiation on the pyrite surface. Electrochim. Acta 2014, 127, 416-426. [CrossRef]

40. Jeong, H.Y.; Han, Y.-S.; Park, S.W.; Hayes, K.F. Aerobic oxidation of mackinawite (FeS) and its environmental implication for arsenic mobilization. Geochim. Cosmochim. Acta 2010, 74, 3182-3198. [CrossRef]

41. Shu, D.; Chen, T.; Zou, X.; Li, M.; Wang, C.; Wang, H.; Han, Z.; Liu, H. Effect of iron minerals during coaling on the transformation of NO in the presence of NH3: Take pyrite as an example. Sci. Total Environ. 2020, 731, 138951. [CrossRef]

42. Jovanović, D. Kinetics of thermal Decomposition of pyrite in an inert atmosphere. J. Therm. Anal. Calorim. 1989, 35, 1483-1492. [CrossRef]

43. Zhou, Y.; Xu, P.; Cheng, H.; Liu, Q. Thermal phase transition of pyrite from coal. J. Therm. Anal. Calorim. 2018, 134, 2391-2396. [CrossRef]

44. Lambert, J.M.; Simkovich, G.; Walker, P.L. The kinetics and mechanism of the pyrite-to-pyrrhotite transformation. Met. Mater. Trans. A 1998, 29, 385-396. [CrossRef]

45. Gong, Y.; Tang, J.; Zhao, D. Application of iron sulfide particles for groundwater and soil remediation: A review. Water Res. 2016, 89, 309-320. [CrossRef] [PubMed]

46. Lu, C.; Chiu, H. Adsorption of zinc(II) from water with purified carbon nanotubes. Chem. Eng. Sci. 2006, 61, 1138-1145. [CrossRef]

47. Asencios, Y.J.; Sun-Kou, M.R. Synthesis of high-surface-area $\gamma-\mathrm{Al}_{2} \mathrm{O}_{3}$ from aluminum scrap and its use for the adsorption of metals: $\mathrm{Pb}(\mathrm{II}), \mathrm{Cd}(\mathrm{II})$ and $\mathrm{Zn}(\mathrm{II})$. Appl. Surf. Sci. 2012, 258, 10002-10011. [CrossRef]

48. Grover, V.A.; Hu, J.; Engates, K.E.; Shipley, H.J. Adsorption and desorption of bivalent metals to hematite nanoparticles. Environ. Toxicol. Chem. 2011, 31, 86-92. [CrossRef] [PubMed]

49. Kalavathy, H.; Karthik, B.; Miranda, L.R. Removal and recovery of Ni and Zn from aqueous solution using activated carbon from Hevea brasiliensis: Batch and column studies. Colloids Surf. B Biointerfaces 2010, 78, 291-302. [CrossRef] [PubMed]

50. Rao, R.A.K.; Ikram, S.; Ahmad, J. Adsorption of $\mathrm{Pb}$ (II) on a composite material prepared from polystyrene-alumina and activated carbon: Kinetic and thermodynamic studies. J. Iran. Chem. Soc. 2011, 8, 931-943. [CrossRef]

51. Kim, S.A.; Kamala-Kannan, S.; Lee, K.-J.; Park, Y.-J.; Shea, P.J.; Lee, W.-H.; Kim, H.-M.; Oh, B.-T. Removal of Pb(II) from aqueous solution by a zeolite-nanoscale zero-valent iron composite. Chem. Eng. J. 2013, 217, 54-60. [CrossRef] 